\title{
Meninjau Kembali Tujuan Pendirian dan Fungsi Museum-museum di Kompleks Taman Wisata Candi Borobudur
}

\author{
Isni Wahyuningsih \\ Balai Konservasi Borobudur \\ Email : Isni.wahyuningsih@gmail.com
}

\begin{abstract}
Sumberdaya budaya tidak akan dirasakan manfaatkan oleh masyarakat apabila informasi tentang sumberdaya budaya tersebut tidak disajikan atau dipresentasikan secara luas. Ada berbagai cara untuk menyajikan sumberdaya tersebut, antara lain melalui museum. Salah satu sumberdaya budaya terpenting di Indonesia yang memiliki museum adalah Candi Borobudur, yang telah masuk dalam Warisan Dunia nomor C592 tahun 1991. Keberadaan Candi Borobudur sebagai Warisan Budaya Dunia selalu dimonitor oleh UNESCO, termasuk juga isu yang terkait dengan pengalaman pengunjung serta keberadaan museum-museum di Kompleks Candi Borobudur.

Penelitian ini untuk meninjau kembali keberadaan museum-museum di kompleks Candi Borobudur terkait dengan fungsi dan tujuan pendiriannya. Untuk itu langkah yang dilakukan adalah dengan menelusuri terlebih dahulu tujuan dan fungsi pendirian museum situs. Selanjutnya pengumpulan data kenyataan yang ada dihimpun melaui pengamatan atau observasi, wawancara serta penyebaran kuesioner terhadap responden. Hasil analisis menunjukkan bahwa fungsi dan tujuan pendirian museum-museum situs di kompleks Candi Borobudur belum optimal.
\end{abstract}

Kata Kunci: Warisan Budaya Dunia, museum, Candi Borobudur

\begin{abstract}
Cultural resource would not be considered useful by the community if the information about the cultural resources are not represented widely. There are several ways to represent the resources, namely through museum. One of the most important cultural resource in Indonesia which has museum is Borobudur Temple that had been inscribed in the World Heritage List number C 592 year of 1991. As the site that have been enlisted in the World Cultural Heritage List, its state of conservation is always monitored by UNESCO. The monitoring includes the issues related with visitor's experience as well as the site museum existence at the complex of Borobudur Temple.

The research was aimed to review museums existence in Borobudur Temple Complex in terms of its functions and purpose. The step used was by collecting the data which was obtained through observation, interview and questionnaire distribution towards the respondent, and library study. Then, the data obtained was tabulated so that the result could be used to support the evaluation. The results show that the function and purpose of the extant museums in Borobudur Temple Complex are not in accordance with with the proper aims of the establishment of the museums.
\end{abstract}

Keywords: World Cultural Heritage, museum, Borobudur Temple

\section{A. Pendahuluan}

Indonesia kaya akan sumberdaya budaya bahkan telah diakui oleh dunia. Namun sumberdaya budaya tersebut akan dirasakan manfaatnya oleh masyarakat apabila terdapat informasi tentang sumberdaya budaya tersebut disajikan atau dipresentasikan secara luas. Salah satu cara untuk menyajikan sumberdaya tersebut, antara lain melalui museum. Menurut lembaga permuseuman dunia ICOM, museum dijelaskan sebagai lembaga nirlaba dan permanen untuk melayani masyarakat, dan terbuka untuk umum. Tugas lembaga ini adalah mengumpulkan, merawat, meneliti, mengkomunikasikan dan memamerkan benda-benda/bukti tentang manusia dan lingkungannya untuk kepentingan penelitian, pendidikan, dan rekreasi (ICOM, 2007).
Salah satu sumberdaya budaya di Indonesia yang memiliki museum situs adalah Candi Borobudur. Kompleks Candi Borobudur kemudian diakui dan terdaftar dalam World Heritage Nomor 348 pada tanggal 13 Desember 1991, kemudian diperbaharui menjadi nomor C 592 tahun 1991. Penetapan Candi Borobudur sebagai warisan dunia merupakan bukti pengakuan internasional terhadap karya besar nenek moyang bangsa Indonesia. Sebagai konsekuensi, situs yang telah masuk dalam daftar warisan budaya dunia akan dimonitor dan dievaluasi terus menerus pengelolaannya oleh UNESCO. Lembaga ini memiliki kewenangan untuk mencabut status objek dan situs yang telah ditetapkan dari daftar warisan dunia, apabila warisan budaya itu tidak dikelola dengan baik oleh negara-negara yang memilikinya. 
Kompleks taman wisata Candi Borobudur dilengkapi dengan fasilitas pendukung, antara lain berupa taman yang mengelilingi candi, museum, ruang audiovisual, hotel, restoran, dan kios cinderamata. Museum yang terdapat di kompleks taman wisata Candi Borobudur saat ini yaitu Museum Borobudur (Museum Karmawibhangga), MURI (Museum Rekor Indonesia) yang kemudian berganti nama GUSBI (Gabungan Seniman Borobudur Indonesia), dan Museum Kapal Samudraraksa. Ketiga museum tersebut berada di jalur wisata untuk kunjungan umum. Selain ketiga museum tersebut, terdapat satu lagi museum yang berada di luar jalur wisata umum, yaitu Studio Sejarah Restorasi Candi Borobudur. Keberadaan museum ini diharapkan mampu menjadi media yang membantu wisatawan atau pengunjung untuk mendapatkan pengetahuan yang lebih banyak tentang sumberdaya yang ada di situs itu yaitu Candi Borobudur. Namun, pada kenyataannya museum situs tersebut ini dirasakan belum memberikan informasi yang cukup tentang Candi Borobudur. Hal tersebut terlihat antara lain dari sedikitnya prosentase jumlah pengunjung museum, dibandingkan dengan pengunjung taman wisata secara keseluruhan.

Pada tahun 2003 diadakan Reactive Monitoring Mission of Borobudur Temple Compounds oleh WHCICOMOS yang dihadiri hampir seluruh instansi yang terkait dengan pengelolaan kawasan Candi. Salah satu isu yang digulirkan saat itu adalah mengenai minimnya pengalaman pengunjung, yang secara tidak langsung berkait dengan peran museum. Salah satu butir rekomendasi yang dihasilkan dari monitoring ini dinyatakan dalam dokumen World Heritage Commision....... sebagai berikut (Boccardi, 2006 ):

"Endorses the national policy to improve the interpretation of the World Heritage value of the property to visitors, giving due emphasis to the local cultural history, intangible cultural heritage, meditative cultural practices which contribute to promote understanding of the spiritual and artistic values for which the property was recognized as World Heritage"

(Menyetujui kebijakan nasional untuk meningkatkan penafsiran nilai Candi Borobudur sebagai Warisan Dunia kepada pengunjung, memberikan penekanan pada sejarah budaya yang bersifat lokal, warisan budaya tak benda, praktek-praktek budaya meditasi yang membantu meningkatkan pemahaman akan nilai-nilai spiritual dan artistik yang dimiliki Candi Borobudur sebagai Warisan Dunia).

Pernyataan ini menunjukkan bahwa museum yang ada di kompleks Candi Borobudur belum memberikan penafsiran dan penyajian informasi yang memadai tentang Candi Borobudur sebagai Warisan Dunia.

Kemudian pada tahun 2006 diadakan Reactive Monitoring Misison of Borobudur Temple Compounds oleh WHC-ICOMOS dengan melibatkan seluruh instansi yang terkait dengan pengelolaan kawasan Candi Borobudur. Terkait dengan kondisi museum di kompleks Candi Borobudur, tim monitoring menyatakan agar:

"Improve the interpretation at the site Museum according to the standard of the Ship Museum, and provide brochures in foreign languages at the latter, including reference to the status of Borobudur as a World Heritage property and the reasons why it was inscribed on the World Heritage List"

(Meningkatkan interpretasi pada museum situs sesuai dengan standar Museum Kapal, dan memberikan brosur dalam bahasa asing, termasuk referensi untuk status Borobudur sebagai World Heritage dan alasan mengapa hal itu tertulis dalam Daftar Warisan Dunia).

Catatan yang diberikan oleh Tim Monitoring WHC - Icomos ini mengapresiasi adanya peningkatan penafsiran terhadap Candi Borobudur pada Museum Kapal Samudraraksa dan berharap agar museum-museum yang lainnya dapat ditingkatkan kualitas penyajiannya.

\section{Metode Penelitian}

Dalam penelitian ini data yang digunakan terdiri dari data primer dan data sekunder. Sesuai dengan kebutuhan data tersebut, maka pengumpulan data yang dibutuhkan dalam penelitian ini adalah sebagai berikut.

1. Observasi atau pengamatan dilakukan dengan cara mengamati museum-museum di kompleks Candi Borobudur dan mengumpulkan segala fakta yang berkaitan dengan museum-museum tersebut seperti kondisi bangunan, koleksi, pengunjung, SDM, dan menghitung jumlah pengunjung di museum-museum di kompleks tersebut. Selain itu juga dilakukan pengamatan terhadap fasilitas-fasilitas lain dan juga kondisi keseluruhan area di kompleks Candi Borobudur serta mengamati alur kunjung, perilaku pengunjung, dan lama kunjung. 
2. Wawancara dan penyebaran kuesioner dilakukan untuk mendapatkan data yang belum terhimpun melalui pengamatan. Wawancara dilakukan secara langsung dilakukan terhadap beberapa sumber antara lain pengelola museum dan pengunjung.

3. Pengumpulan data sekunder dilakukan dengan pengumpulan data literatur dan studi-studi terdahulu terkait dengan penelitian. Metode analisis deskriptif, yaitu memberikan uraian secara gamblang tentang kondisi atau situasi yang terjadi di wilayah studi. Untuk mendukung penjelasan tersebut disertai dengan grafik atau tabel. Uraian yang dipaparkan sebagai hasil penelitian terdiri dari berbagai aspek sebagai berikut

4. Analisis data didasarkan pada fakta yang diperoleh melalui observasi dan survey di lapangan, yang akan menunjukkan data mengenai: a) Kondisi eksisting di lapangan yang meliputi atraksi lain yang ditawarkan serta kondisi kawasan, tata letak ojek pendukung yang di dalamnya termasuk museum, infrakstruktur, dan pengunjung Candi Borobudur sehingga nantinya dapat diketahui karakteristik kawasan wisata Candi Borobudur; b). Pola pergerakan yang akan memberi gambaran pergerakan aktivitas pengunjung yang dilakukan di kawasan wisata dari pintu ticketing sampai pintu keluar; c). Tingkat kunjungan ke museum-museum di kompleks Candi Borobudur. Perbandingan kondisi aktual di lapangan terkait dengan fungsi dan tujuan pendirian museum-museum situs di Kompleks Candi Borobudur sebagai bagian dari objek/fasilitas pendukung taman wisata Candi Borobudur dengan tujuan potensial yang diharapkan sesuai dengan masterplan JICA 1979, dan dokumendokumen lainnya yang terkait dengan pendirian museum-museum tersebut.

\section{Tujuan Pendirian Museum - Museum di Kompleks Candi Borobudur}

\section{a. Fungsi Museum di Kompleks Taman Wisata}

\section{Candi Borobudur}

Kompleks taman wisata Candi Borobudur ini dibangun berdasarkan masterplan JICA tahun 1979. Masterplan tersebut merupakan konsep yang disusun oleh Pemerintah Indonesia dan Jepang untuk melestarikan dan mengelola kawasan candi borobudur setelah pemugaran selesai. Konsep ini sebenarnya diarahkan pada pendirian Taman Purbakala Nasional (National Archaelogical Park). Rancangan masterplan tersebut disusun berdasarkan hasil berbagai kajian sampai dalam tahap persiapan pembangunan. Dalam masterplan tersebut kawasan Borobudur dibagi dalam 5 zona sebagai upaya untuk pelindungan Candi Borobudur. Pembagian zona tersebut adalah sebagai berikut.

1. Zona 1 (Sanctuary Area)

Zona untuk pelindungan dan pencegahan terhadap perusakan lingkungan fisik situs arkeologi Candi Borobudur, sehingga di dalamnya tidak diperbolehkan didirkan bangunan apapun, kecuali candi itu sendiri.

2. Zona II (Taman Wisata)

Zona ini diperuntukkan sebagai pembangunan fasilitas taman untuk kesenangan pengunjung dan pemeliharaan situs bersejarah.

3. Zona III

Zona ini untuk pengaturan penggunaan tanah (land use) di sekitar taman dan pelindungan terhadap lingkungan, dan pengontrolan area di sekitar taman.

4. Zona IV

Zona untuk pemeliharaan benda-bend bersejarah dan pencegahan terhadap perusakan benda-benda tersebut.

5. Zona $\mathrm{V}$

Zona untuk keperluan survei arkeologi dan pencegahan terhadap perusakan monumen arkeologi yang belum ditemukan (JICA, 1979).

Dalam rencana induk pembangunan kompleks taman wisata Candi Borobudur dilengkapi dengan fasilitas - fasilitas sebagai berikut.

1. Fasilitas pokok

a. Pusat Studi Borobudur

b. Pusat Konservasi Batu

c. Museum Arkeologi

2. Fasilitas Operasional

d. Kantor Unit Taman Wisata

e. Kantor Pemeliharaan Taman

f. Kantor Penerangan

g. Kebun Pembibitan

h. Gardu jaga

i. Loket penjualan karcis

3. Fasilitas pelayanan 

j. Kios-kios souvenir
k. Restoran
I. Tempat parkir
m. Mushola
n. Pergola/shelter
o. Toilet

Berdasarkan masterplan, taman wisata yang membentang di zona II di kompleks Candi Borobudur selain berfungsi sebagai sabuk pengaman hijau (safety green belt), juga mempunyai fungsi lainnya yaitu sebagai berikut.

1. Sebagai peredam terhadap pengunjung candi pada saat padat pengunjung agar tidak bersamaan menaiki candi. Diharapkan pengunjung akan terpecah dan memencar ke berbagai fasilitas wisata yang ada di dalam taman. Harapannya, dengan adanya taman beserta fasilitasnya pengunjung dapat diarahkan sehingga tidak terlalu membebani candi.

2. Mengurangi jumlah pengunjung yang ingin menaiki candi, mereka dapat mengetahui hal ikhwal Candi Borobudur dengan mengunjungi fasilitas umum berupa museum, pusat penerangan, dan Balai Konservasi Borobudur.

3. Memberikan informasi yang memadai kepada pengunjung tentang Borobudur dari berbagai sudut pandang diantaranya sejarah, arsitektur, agama, filsafat, seni, dan ilmu pengetahuan lainnya.

4. Memberikan kesempatan kepada pengunjung untuk melihat candi dari kejauhan dari arah ataupun jarak yang berbeda-beda.

5. Untuk lebih menampakkan keagungan dan keanggunan candi.

6. Untuk lebih menanamkan rasa cinta tanah air khususnya bagi generasi muda, dengan lebih mengenali, menghayati, mendalami, mempelajari candi sebagai hasil karya agung nenek moyang.

7. Untuk memelihara dan mengembangkan tanaman langka yang perlu dijaga kelestariannya untuk generasi mendatang (JICA, 1979 : Yuwono, 2014 : 148; Tanudirjo, dkk, 1993-1994: 132).

Uraian di atas menunjukkan bahwa museum sebagai bagian dari fasilitas yang ada di kompleks taman wisata mempunyai fungsi untuk meredam dan memencarkan pengunjung agar tidak menaiki candi secara bersamaan sehingga membebani candi. Selain itu, fungsi museum juga memberikan informasi tentang
Candi Borobudur secara memadai dari aspek sejarah, arsitektur, agama, filsafat, seni, dan ilmu pengetahuan lainnya.

Dalam masterplan JICA disebutkan adanya museum arkeologi adalah Museum Karmawibhangga (kemudian diubah namanya menjadi Museum Borobudur pada tahun 2010). Namun kemudian pada tahun-tahun selanjutnya di Zona II terdapat penambahan fasilitas MURI (Museum Rekor Indonesia) yang kemudian berganti menjadi GUSBI pada tahun 2005, Museum Kapal Samudraraksa pada tahun 2005, dan Studio Sejarah Restorasi Candi Borobudur pada tahun 2011. Pada intinya ketiga museum yang dibangun setelah Museum Karmawibhangga (Borobudur) juga merupakan fasilitas di taman wisata, sehingga mempunyai fungsi yang sama yaitu untuk memecah dan memencarkan pengunjung serta memberikan informasi terkait dengan Candi Borobudur.

\section{b. Tujuan Pendirian Masing - Masing Museum di Kompleks Candi Borobudur.}

Keempat museum situs di Kompleks Candi Borobudur selain mempunyai tujuan umum sebagai bagian dari pendukung keberadaan taman wisata, namun begitu masing-masing museum juga mempunyai tujuan pendirian pendirian yang berbeda-beda. Tujuan masingmasing museum tersebut adalah sebagai berikut.

1. Museum Karmawibhangga (kemudian diubah namanya menjadi Museum Borobudur pada tahun 2010)

Tujuan pendirian museum ini adalah untuk pelayanan atau fasilitas informasi yang dapat memberikan pengetahuan yang memadai kepada pengunjung tentang Candi Borobudur dari berbagai sudut pandang diantaranya sejarah, arsitektur, agama, filsafat, seni, dan aspek keilmuan lainnya. Diharapkan dengan mendapatkan informasi yang memadai akan timbul rasa cinta tanah air khususnya bagi generasi muda. Diharapkan pengunjung dapat dengan lebih mengenali, menghayati, mendalami, mempelajari candi sebagai hasil karya agung nenek moyang. Museum ini dirancang menjadi objek yang menarik setelah candi, dan sebagai salah satu fasilitas untuk memecah pengunjung agar tidak membebani candi (JICA, 1979 ; Ideco Utama, 1981). 
2. Museum Kapal Samudraraksa (didirikan pada tahun 2005)

Tujuan pendirian Museum Kapal Samudraraksa diharapkan dapat menjadi ilham untuk mendorong tumbuhnya semangat dan budaya bahari bangsa Indonesia. Misi museum tersebut yaitu untuk membangkitkan kembali semangat dan budaya bahari bangsa Indonesia. Adapun tema besar yang dicanangkan adalah Membangkitkan Semangat Bahari Bangsa Indonesia dalam Millenium ke-3 (Tanudirjo, 2004: 4-5).

3. MURI (pada tahun 2005 berganti nama menjadi GUSBI)

Pada awalnya museum ini merupakan Museum Rekor Indonesia (MURI) yang bertujuan untuk memberikan apresisasi terhadap hasil karya anak bangsa yang berprestasi atau memecahkan rekor, unik, atau di luar kelaziman. Kemudian museum tersebut berganti nama menjadi GUSBI (Gabungan Seniman Borobudur Indonesia) yang dimotori oleh seniman Borobudur. Tujuan pendirian museum tersebut adalah untuk memfasilitasi dan memamerkan hasil karya seniman terutama dari wilayah Borobudur dan sekitarnya. Diharapkan dengan adanya museum ini dapat menginspirasi generasi muda untuk berprestasi terbaik sehingga dapat membawa nama harum bangsa Indonesia. (wawancara dengan Ibu Sri Sariningsih, pengelola museum)

4. Studio Restorasi Candi Borobudur (didirikan pada tahun 2011)

Tujuan didirikannya Studio Sejarah Restorasi Candi Borobudur untuk mendokumentasikan dan memamerkan peralatan dan informasi yang berkaitan dengan restorasi Candi Borobudur mulai dari Pemugaran I, sampai masa pemugaran II. Keberadaan Studi Sejarah Restorasi Candi Borobudur diharapkan mampu menjadi media penyebaran informasi tentang Candi Borobudur dan media pembelajaran terhadap generasi muda (Balai Konservasi Borobudur, 2011).

\section{c. Museum Sebagai Objek Wisata}

Dalam pariwisata terdapat tiga komponen yaitu atraksi, pengunjung (visitor), dan infrastruktur (Wall, 1989). Sementara itu, Timothy and Boyd (2003: 158-

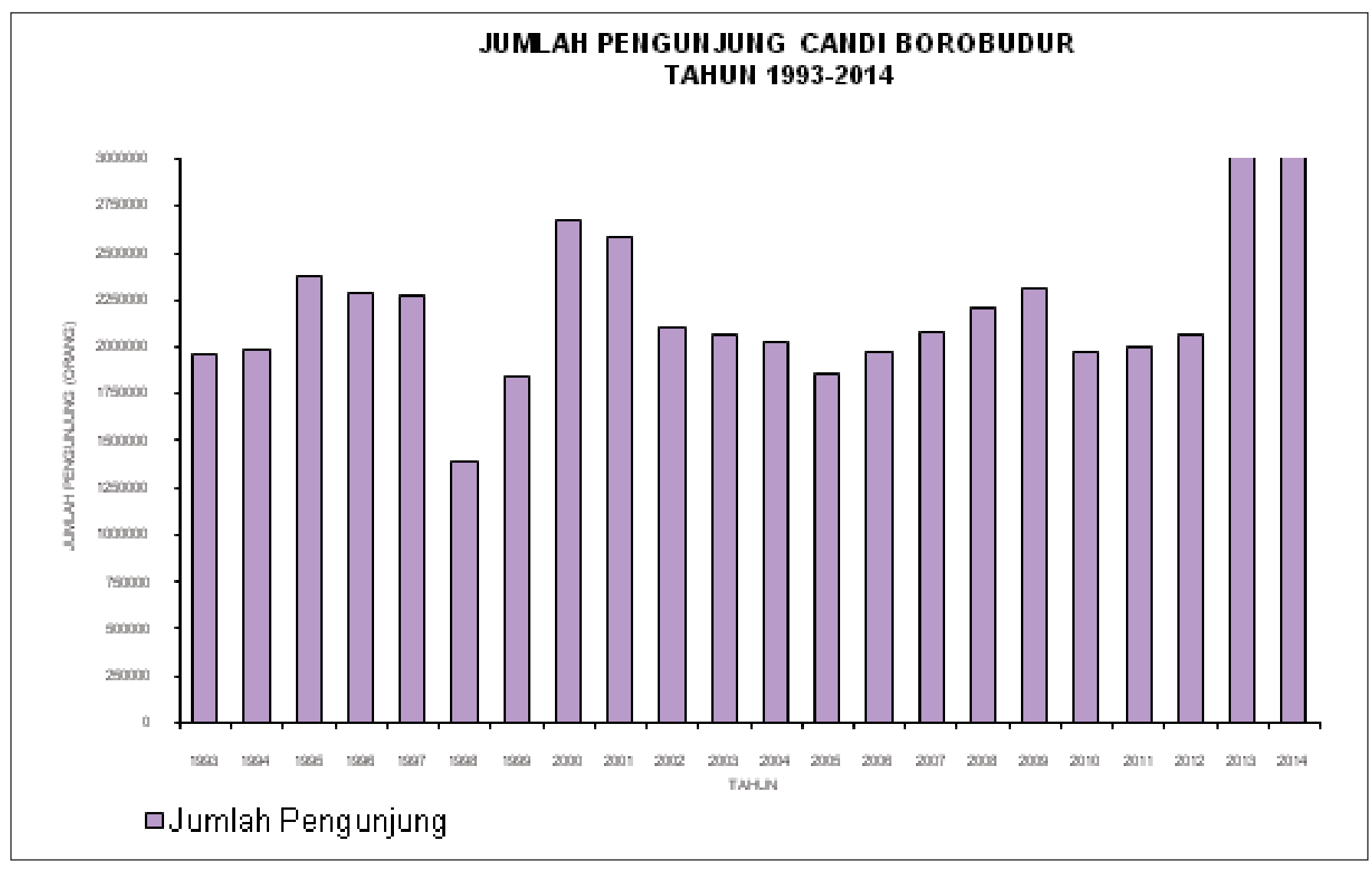

Sumber: PT. Taman Wisata Unit Borobudur dan Balai Konservasi Borobudur 
159) berpendapat bahwa kegiatan kunjungan wisata merupakan aktivitas yang saling terkait antara setting (tata letak), aktivitas, harapan pengunjung/pengguna, dan perangkat aturan manajemen pengelolaan. Di dalam pengelolaan aktivitas kunjungan wisatawan di situs harus selalu dimonitoring dan evaluasi secara berkala agar dampak kehadirannya terhadap pelestarian warisan budaya dapat diketahui.

Candi Borobudur merupakan salah satu ikon pariwisata di Indonesia, dari tahun ke tahun kunjungan wisatawan ke candi Borobudur semakin bertambah jumlahnya setiap tahunnya di atas 2 juta pengunjung, bahkan 2 tahun terakhir sampai menembus angka 3.000.000 pengunjung.

Pengunjung di wisata Candi Borobudur terdiri dari wisatawan asing dan wisatawan nusantara. Untuk mengetahui apakah tujuan dan fungsi museum di kompleks Candi Borobudur telah sesuai dengan apa yang direncanakan perlu diketahui apa pendapat pengunjung tentang keberadaan museum-museum tersebut. Survey dilakukan terhadap 200 sampel pengunjung yang diambil secara acak. Profil demografi responden sebagai berikut

\section{Jenis Kelamin}

Responden dari kelompok pria dan wanita mempunyai perbandingan yang hampir sama berkisar antara 55\% untuk responden pria dan 45\% untuk responden wanita.

\section{Usia dan pekerjaan}

Responden yang diambil secara acak menunjukkan bahwa mereka mempunyai rentang usia antara 1550 tahun, dan berbagai latar belakang profesi sebagai pelajar, mahasiswa, karyawan, pegawai negeri, dan wiraswasta.

Sementara itu untuk profil psikografi sebagian besar responden adalah sebagai berikut.

\section{Bentuk kunjungan}

Sebagian besar responden melakukan perjalanan wisata ke Candi Borobudur dengan model kedatangan secara rombongan (49\%). Kebanyakan merupakan rombongan study tour (ketika liburan sekolah), karyawan suatu instansi/perusahaan maupun rombongan dari wilayah domisili wisatawan. Kunjungan bersama keluarga (32\%) selebihnya kunjungan bersama teman dan individu (19\%).

\section{Frekuensi kunjungan}

Responden yang telah melakukan kunjungan 2 kali (28\%), 3-4 kali (16\%) dan lebih dari 5 kali (10\%), sehingga kisaran yang telah melakukan kunjungan ulang \pm sebanyak 54\%. Selebihnya (46\%) kunjungan ke Borobudur merupakan pengalaman pertama kali.

\section{Lama Kunjungan}

Sebagian besar responden berada di taman wisata Candi Borobudur rata-rata selama 1-2,5 jam (69\%), sedangkan yang lebih dari 2,5 jam ada 21\% dan yang kurang dari 1 jam (10\%). Dari hasil pengamatan diketahui lama kunjungan rata-rata wisatawan, naik ke candi selama 30-60 menit, menikmati halaman atau pelataran candi 15-30 menit dan di area taman (Zona II) selama 25-60 menit.

\section{Motivasi Kunjungan}

Motivasi kunjungan menunjukkan bahwa responden memutuskan untuk berkunjung ke Candi Borobudur untuk alasan hiburan atau rekreasi mencapai 54,5\%, alasan pendidikan sebanyak 19\%, alasan untuk menyenangkan keluarga/anak-anak sebesar 25\%, dan selebihnya untuk alasan ketiga-tiganya (hiburan, pendidikan dan menyenangkan anak-anak) sebanyak $1,5 \%$.

Berdasarkan pengamatan pola pergerakan pengunjung, dapat diketahui $97 \%$ pengunjung di

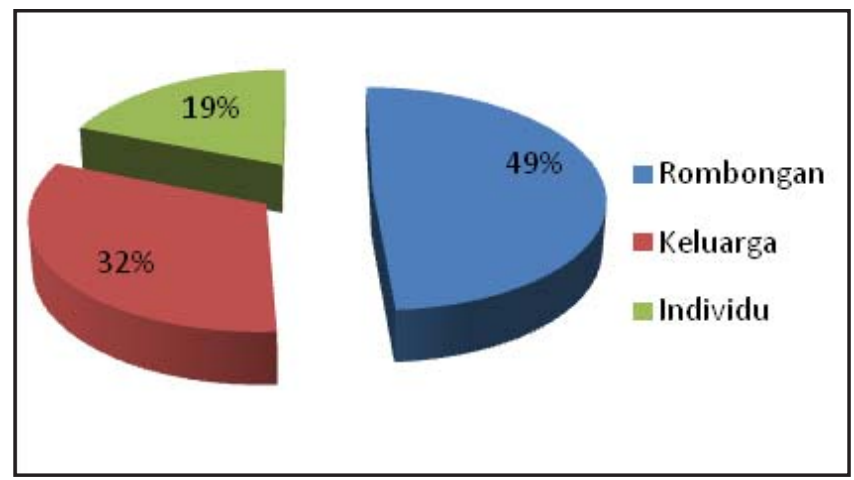

Diagram 1. Bentuk Kunjungan

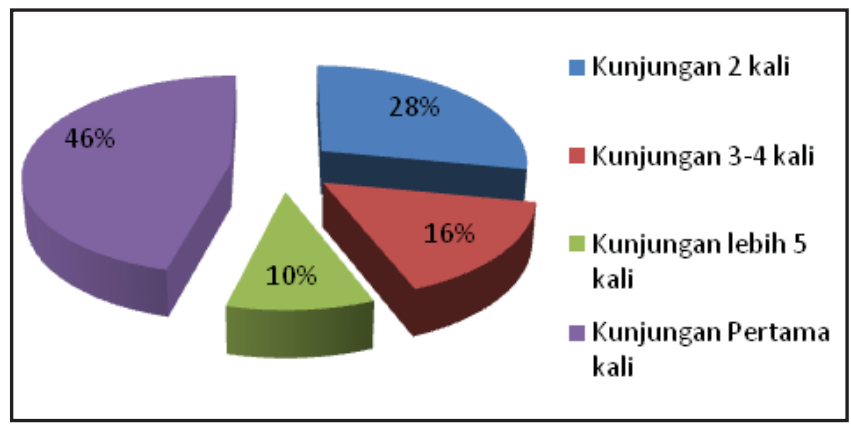

Diagram 2. Frekuensi Kunjungan 
komplek taman wisata Candi Borobudur langsung dari pintu ticketing menuju zona I atas (pelataran candi), dan 3\% lainnya karena faktor usia dan kesehatan hanya berada di bawah, duduk-duduk di area taman (Zona I luar dan Zona II). Sementara di Zona I Atas (pelataran candi) sebagian besar pengunjung langsung naik ke teras dan stupa induk sebesar $70 \%$. Berdasarkan pengamatan dapat diketahui kisaran lama kunjungan wisatawan, naik ke candi selama berkisar 30-60 menit, menikmati halaman berkisar 15-30 menit, dan di area taman (zona II) berkisar 25-60 menit. Prosentase terbesar pergerakan pengunjung ke arah atraksi wisata yang lokasinya searah seperti pola 1 yaitu pintu masuk/ticketing - candi- pintu keluar, terutama pada saat padat kunjungan. Kemudian disusul

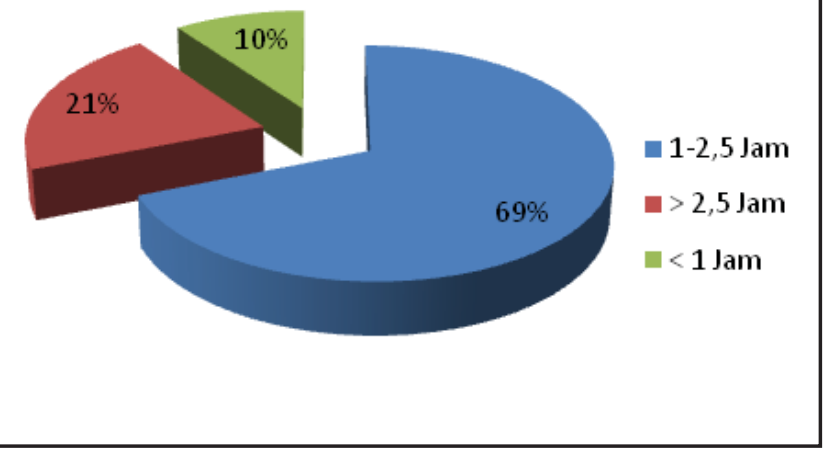

Diagram 3. Lama Kunjungan

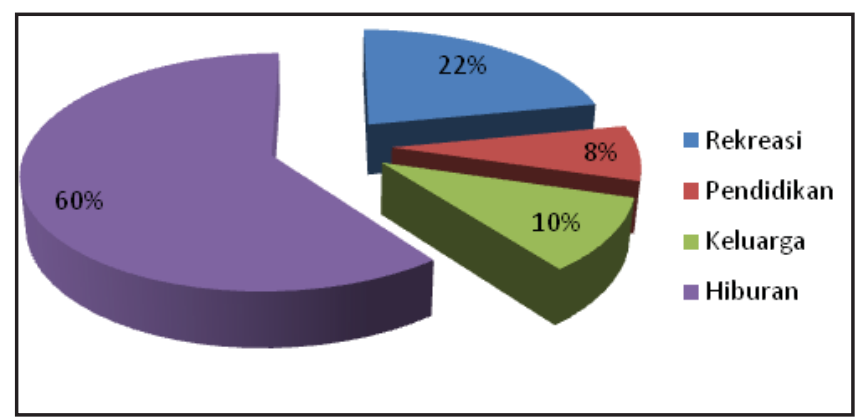

Diagram 4. Motivasi Kunjungan

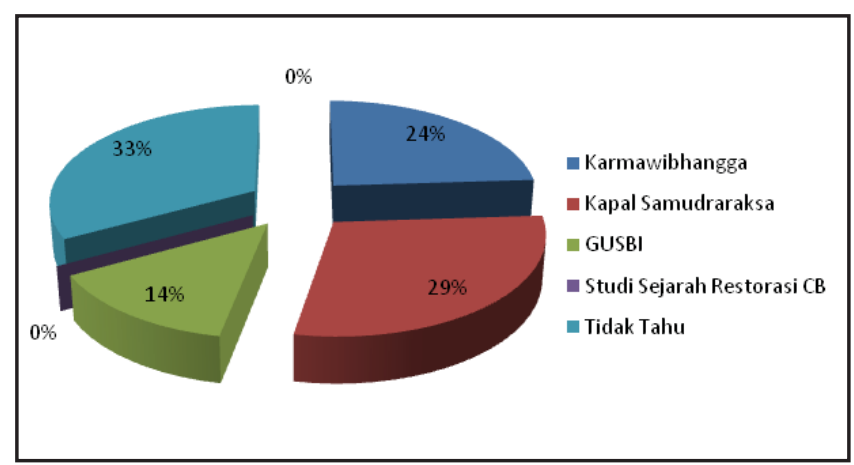

Diagram 5. Pengetahuan Pengunjung tentang Keberadaan Museum di Kompleks Candi Borobudur dengan pola 2 , dimana pola tersebut mempunyai lokasi yang searah dengan jalur keluar. Pergerakan pengunjung belum optimal mencakup ke seluruh lokasi atraksi wisata yang sudah disediakan oleh pengelola taman wisata.

Berdasarkan hasil survei melalui wawancara maupun penyebaran kuesioner kepada 200 sampel pengunjung sebagai responden yang diambil secara acak, diketahui bahwa pengunjung sebagian besar tidak tahu akan keberadaan museum-museum tersebut. Responden yang mengetahui keberadaan fasilitas Museum Karmawibhangga sebesar 24\%, Museum Kapal Samudraraksa sebesar 29 \%, MURI/GUSBI sebesar $14 \%$, dan Studio Sejarah Restorasi Candi Borobudur sebesar $0 \%$. Sementara yang menjawab tidak menjawab sebesar $33 \%$ responden.

Keberadaan Museum Kapal Samudraraksa dan Museum Borobudur lebih banyak diketahui pengunjung dibandingkan GUSBI, sedangkan keberadaan Studio Sejarah Restorasi Candi Borobudur tidak diketahui. Berdasarkan pengamatan, hal tersebut dikarenakan lokasi dari Museum Kapal Samudraraksa dan Museum Karmawibhangga berada searah atau satu jalur yang dilewati pengunjung ketika menuju pintu keluar. Dengan demikian posisi yang lebih strategis itu menyebabkan pengunjung lebih mudah mengetahui keberadaannya. Keberadaan Studio Sejarah Restorasi memang masih belum banyak diketahui, karena posisinya berada di luar area/jalur kunjungan wisata untuk umum. Keberadaan GUSBI yang berlokasi jauh dari jalur pintu keluar, menjadikan pengunjung kurang mengetahui lokasi museum tersebut.

Rata-rata pengunjung Taman Wisata Borobudur kurang lebih 5.000 orang per hari, dan total pengunjung per tahun dapat menembus angka 3.000.000 orang per tahun. Saat padat kunjungan pada musim liburan sekolah, liburan natal \& tahun baru, liburan Lebaran pengunjung dapat mencapai 50.000 orang per hari, dengan rata-rata dalam satu jam kurang lebih 5.000 orang naik bersamaan ke bangunan candi. Namun dari jumlah pengunjung yang mencapai ribuan orang tersebut, hanya sedikit yang mengunjungi museum-museum di kompleks taman wisata Candi Borobudur. Berikut sampel pengamatan dan penghitungan terhadap wisatawan yang mengunjung GUSBI, Museum Kapal Samudraraksa dan Museum Karmawibhanga. Pengamatan dilakukan selama jam 
Table 1. Sampel Pengamatan Pengunjung GUSBI, Museum Samudraraksa dan Museum Borobudur Pada Saat Liburan Nyepi

\begin{tabular}{|c|c|c|c|c|}
\hline \multirow[t]{2}{*}{ JAM } & \multicolumn{3}{|c|}{ JUMLAH PENGUNJUNG (ORANG) } & \multirow[t]{2}{*}{ KETERANGAN } \\
\hline & MURI GUSBI & MUSEUM BOROBUDUR & MUSEUM SAMUDRARAKSA & \\
\hline 06-07 & - & - & - & Total jumlah \\
\hline 07-08 & 3 & 8 & 6 & pengunjung \\
\hline $08-09$ & 7 & 26 & 18 & 37.859 orang \\
\hline $09-10$ & 36 & 78 & 43 & \\
\hline $10-11$ & 87 & 102 & 73 & \\
\hline $11-12$ & 95 & 112 & 84 & \\
\hline $12-13$ & 148 & 185 & 97 & \\
\hline $13-14$ & 115 & 211 & 93 & \\
\hline $14-15$ & 89 & 144 & 45 & \\
\hline $15-16$ & 31 & 67 & 25 & \\
\hline $16-17$ & 7 & 26 & 11 & \\
\hline TOTAL & 618 & 959 & 495 & \\
\hline
\end{tabular}

kunjung, yaitu dari mulai pukul 06.00 - 17.00 WIB, dengan mengamati pengunjung di GUSBI, Museum Borobudur dan Museum Samudraraksa. Pengamatan dilakukan dengan cara menghitung pengunjung (per satu jam) yang masuk ke museum-museum tersebut.

Hasil pengamatan tersebut menunjukkan bahwa pengunjung di ketiga museum tersebut berkisar antara 1 - 2,5\% dari total pengunjung di taman wisata Candi Borobudur. Dari total pengunjung yang mengunjungi museum, hanya separuhnya saja yang benar-benar mengamati koleksi museum. Jumlah pengunjung lebih banyak pada siang hari (kisaran jam 11.00 - 14.00). Pada jam-jam tersebut cukup terik, dan kemungkinan besar pengunjung lebih terdorong masuk ke museum untuk alasan mencari tempat yang teduh. Di Museum Karmawibahnagga/Borobudur, tempat yang paling disukai di pendopo, duduk beristirahat setelah lelah menaiki candi, sambil menunggu teman/family dalam satu rombongan yang terpisah dan mencari toilet.

Opini responden terhadap kualitas pengalaman yang didapat menunjukkan sebagian besar responden berkomentar baik/senang terhadap objek wisata yang berfokus pada produk utama, yaitu Candi Borobudur itu sendiri. Pendapat yang positif juga diberikan terhadap upaya yang dilakukan oleh pihak pengelola untuk memelihara candi dan taman sekitarnya, terutama aspek kebersihan dan keindahan lingkungan taman. Namun demikian, pengunjung juga menyatakan keluhan-keluhan terhadap perilaku penjual asongan yang memaksa, sehingga responden terganggu. Selain itu keluhan disampaikan terkait jarak yang jauh antara tempat parkir dan objek wisata serta jalan keluar yang dianggap sulit atau berputar-putar. Kesulitan mendapatkan toilet di dekat candi; kurangnya tempat istirahat dan berteduh saat hujan/panas; dan kebersihan tempat parkir dan toilet juga dikeluhkan oleh sebagian besar pengunjung.

Terrkait status Candi Borobudur sebagai warisan budaya dunia banyak pengunjung yang ternyata tidak tahu. Berdasarkan hasil survey hanya sebanyak $56 \%$ responden tahu bahwa Candi Borobudur sebagai warisan dunia, selebihnya menjawab tidak tahu. Meskipun pengunjung yang tahu status Candi Borobudur sebagai warisan budaya dunia lebih dari $50 \%$, tetapi mereka yang tidak tahu juga jumlahnya amat banyak. Sementara itu, terkait dengan informasi Candi Borobudur diketahui bahwa pengunjung merasa belum mendapatkan informasi yang memadai tentang Candi Borobudur (96\%). Pengunjung ketika mulai masuk taman melalui pintu ticketing, tidak mendapatkan pengetahuan/informasi tentang Candi Borobudur secara memadai (minimnya booklet, leaflet, dan sebagainya), ketika keluar juga tidak banyak mendapatkan informasi tentang Borobudur (informasi yang diberikan museum).

Minimnya kunjungan ke museum di Taman Wisata selain dipengaruhi oleh gangguan dari pedagang asongan/lapak pedagang, juga disebabkan faktor luasnya area taman. Setiap lokasi objek wisata dihubungkan dengan jalur pejalan kaki. Namun keberadaan jalur pejalan 
kaki tersebut belum dapat mengarahkan pengunjung untuk melakukan pergerakan secara optimal. Penempatan museum setelah kunjungan ke candi, menjadikan pengunjung sudah dalam kondisi lelah. Kurang jelasnya tanda-tanda penunjuk, faktor lama waktu kunjungan, dan kurangnya promosi dari pihak pengelola, faktor psikografi pengunjung seperti motivasi kunjungan dari wisatawan itu sendiri mempengaruhi tinggi rendahnya minat untuk melihat dan menikmati museum.

\section{Kesimpulan}

Pertama, museum sebagai bagian dari fasilitas pendukung wisata di Kompleks Candi Borobudur dapat dikatakan belum menjadi atraksi yang menarik bagi pengunjung. Hal tersebut berdasarkan pada hasil penelitian yang menunjukkan bahwa wisatawan yang mengunjungi museum hanya berkisar $1-2,5 \%$ dari total pengunjung Taman Wisata Candi Borobudur. Sementara itu, responden yang mengetahui keberadaan fasilitas Museum Karmawibhangga sebesar 24\%, Museum Kapal Samudraraksa sebesar $29 \%$, GUSBI sebesar $14 \%$, dan Studio Sejarah Restorasi Candi Borobudur sebesar $0 \%$. Sementara yang menjawab tidak tahu sebesar $33 \%$.

Kedua, museum belum memenuhi fungsinya sebagai infrastruktur atau sarana pemecah dan pemencar pengunjung. Berdasarkan hasil penelitian 97\% pengunjung langsung ke zona I inti (candi dan pelataran) dan $70 \%$ langsung naik ke bangunan candi. Pola pergerakan pengunjung kurang optimal, tidak semua sarana pendukung khususnya museum dapat di kunjungi.

Ketiga, pengelola taman wisata belum memperhatikan pengunjung dengan memberikan pengalaman kunjungan yang optimal. Hal tersebut berdasarkan hasil penelitian yang menunjukkan bahwa responden merasa belum mendapatkan informasi yang memadai tentang Candi Borobudur sebanyak $97 \%$ dan $44 \%$ responden tidak mengetahui status Borobudur sebagai warisan dunia.

Keempat, pengelola belum menempatkan museum sebagai suatu objek yang menarik setelah candi. Museum belum ditempatkan sebagai sarana untuk lebih memahami tentang Candi Borobudur dan aspek terkait lainnya. Museum-museum di Kompleks Taman Wisata Candi Borobudur, belum dapat memberikan setting yang jelas baik bagi Candi Borobudur. Tata letak museum atau jalur kunjung ke museum yang ditempatkan setelah kunjungan ke candi menjadikan fungsi museum sebagai sarana pemberi informasi tentang Candi Borobudur menjadi terabaikan oleh pengunjung.

Kelima, salah satu faktor penyebab minimnya kunjungan museum di Kompleks Taman Wisata Candi Borobudur adalah signage yang kurang jelas dan menarik. Faktor lain yang dapat diidentifikasikan antara lain adalah terbatasnya lama waktu kunjungan, psikografi pengunjung, minimnya promosi, brosur, leaflet, dan lokasi lapak pedagang cinderamata yang menutupi jalurjalur untuk berkunjung ke museum.

Berdasarkan hal tersebut di atas maka dapat ditarik kesimpulan akhir bahwa museum-museum di Kompleks Candi Borobudur belum memenuhi fungsinya secara optimal sebagai atraksi wisata, sarana pelestarian, maupun sebagai infrastuktur pemecah pengunjung.

\section{Saran}

1. Menggeser atau mengubah jalur kunjung, menjadikan museum berada di depan atau diawal kunjungan.

2. Pembatasan jumlah pengunjung sesuai daya tampung untuk kenyamanan pengunjung atau carrying capacity dengan memasang counter pengunjung sebelum memasuki concrouse, sehingga pengunjung yang menunggu giliran naik ke candi dapat mengunjungi objek lain antara lain museum dan objek-objek yang lainnya (perlu penambahan objek lain yang menarik di beberapa spot)

3. Membuat semacam pembedaan jalur berdasarkan lama kunjung dan corcern peminatan bagi pengunjung dengan pembedaan harga tiket (tiket berkelas-kelas) sesuai pilihan tempat yang akan dikunjungi.

4. Pintu masuk pengunjung tidak hanya satu pintu, sehingga pengunjung dapat memasuki area taman wisata Candi Borobudur dari berbagai penjuru.

Sementara itu, untuk mengoptimalkan fungsi museum tersebut dapat dilakukan revitalisasi museum. Revitalisasi dapat dilaksanakan antara lain dalam bentuk meningkatkan kualitas penyajian koleksi, membuat harmoni antara storyline dan permainan media, memperhatikan segmen atau target group pengunjung yang akan dipilih, fasilitas fisik, sumber daya manusia yang memadai, dan struktur organisasi yang tepat. 


\section{DAFTAR PUSTAKA}

Ambrose, Timothy and Paine, Crispin, 2006. Museum Basic. London: Routledge

Ardiyansyah, Panggah, dkk, 2014. Kajian Management Visitor Candi Borobudur Tahap II,. Magelang: Balai Konservasi Borobudur.

Ardika, Wayan, 2007."Museum Sebagai Objek Wisata" dalam Museografia, XXVIII No. 2 Tahun $1999 / 2000$

Balai Konservasi Borobudur, 2012. Kearsitekturan Candi Borobudur.

Balai Konservasi Borobudur, 2012. Candi Borobudur Selayang Pandang.

Boccardi, G; Brooks, G; dan Gurung, H. Maret 2006. Mission Report: Reactive Monitoring Mission to Borobudur Temple Compounds World Heritage Property, Indonesia. Diselenggarakan pada tanggal 18-25 Februari 2006

Balai Konservasi Borobudur, 2013. Laporan Tahunan, Tahun 2013 Balai Konservasi Borobudur. Magelang: Balai Konservasi Borobudur.

Bowes, R.G. 1989. Tourism and Heritage: A New Approach to the Product, Recreation Reseach Review (tidak dipublikasikan)

Edson, Gary, 1994. "Museum Management" in Running a Museum: The Handbook for Museum, ICOM, Prancis, 133-146.

ICOM, 2001. Code of Ethic of Museum. Paris.

Ideco Utama, 1981. Up-dated Former Plans and Schematic Design. Phase I: For orobudur and Prambanan National Archaelogical Parks Project.

JICA, 1979. Masterplan Borobudur Arhaelogical Park. JICA - Departemen Pendidikan Nasional Departemen Perhubungan, Komunikasi dan Pariwisata, Jakarta.
Taman Wisata Candi Borobudur, 1989. Sekilas Taman Wisata. Magelang : PT. TWCB.

Tanudirjo, Daud Aris. 1993-1994. Kualitas Penyajian Warisan Budaya kepada masyarakat: Studi Kasus Menejemen Suberdaya Budaya Candi Borobudur. Yogyakarta: Pusat Antar Universitas-Studi Sosial, Universitas Gadjah Mada. 2004. Rancangan Penataan Museum Kapal Samudraraksa. Laporan Akhir. 2007. "Museum Sebagai Mitra Pendidik" dalam Museografia Vol. I No. I September 2007, hal. 15-32. , 2009.'Melestarikan Warisan Budaya Dunia Kompleks Candi Borobudur : Perspektif Baru". Jurnal Konservasi Benda Cagar Budaya Borobudur. Vol. III No.3 Desember 2009 hlm. 7-10. Magelang: Balai Konservasi Borobudur.

Tantangan Pengembangan Museum Situs
di Indonesia", makalah disampaikan dalam
Kegiatan Workshop Managing Archeological
Site Museum di Solo Jawa Tengah 12-21Oktober
2014.
,2009.’Melestarikan Warisan Budaya Dunia Kompleks Candi Borobudur : Perspektif Baru". Jurnal Konservasi Benda Cagar Budaya Borobudur. Vol. III No.3 Desember 2009 hlm. 7-10. Magelang: Balai Konservasi Borobudur.

Yuwono, Sri Suwito, 2014. "Taman Wisata Candi Borobudur Antara Konsep dan Realisasi” dalam 200 Tabun Penemuan Candi Borobudur. Magelang: Balai Konservasi Borobudur. 